\title{
Diasporas and Transnational Entrepreneurship in Global Contexts
}

Sanya Ojo

University of East London, UK

A volume in the Advances in Business Strategy and Competitive Advantage (ABSCA) Book Series

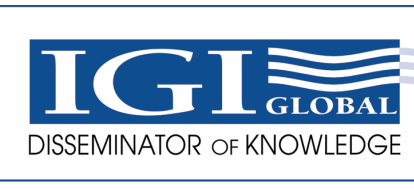

www.igi-global.com 
Published in the United States of America by

IGI Global

Business Science Reference (an imprint of IGI Global)

701 E. Chocolate Avenue

Hershey PA, USA 17033

Tel: 717-533-8845

Fax: 717-533-8661

E-mail: cust@igi-global.com

Web site: http://www.igi-global.com

Copyright (C) 2017 by IGI Global. All rights reserved. No part of this publication may be reproduced, stored or distributed in any form or by any means, electronic or mechanical, including photocopying, without written permission from the publisher. Product or company names used in this set are for identification purposes only. Inclusion of the names of the products or companies does not indicate a claim of ownership by IGI Global of the trademark or registered trademark.

Library of Congress Cataloging-in-Publication Data

CIP Data Pending

ISBN: 978-1-5225-1991-1

eISBN: $978-1-5225-1992-8$

This book is published in the IGI Global book series Advances in Business Strategy and Competitive Advantage (ABSCA) (ISSN: 2327-3429; eISSN: 2327-3437)

British Cataloguing in Publication Data

A Cataloguing in Publication record for this book is available from the British Library.

All work contributed to this book is new, previously-unpublished material. The views expressed in this book are those of the authors, but not necessarily of the publisher.

For electronic access to this publication, please contact: eresources@igi-global.com. 


\title{
Chapter 9 \\ The Impact of Social Networks on "Born Globals": A Case of De-Internationalisation
}

\author{
Qingan Huang \\ University of East London, UK \\ Ellis L. C. Osabutey \\ Middlesex University, UK
}

\author{
Junzhe Ji \\ Tongji University, China \\ Liying Meng \\ The University of Northampton, UK
}

\begin{abstract}
This paper aims to explore the role and impact of entrepreneurs' social networks on the internationalisation of "Born Global" firms, in particular, its de-internationalisation process. The research is based on a case study approach and adopts a series of face to face and online qualitative longitudinal interviews. It provides some useful insights into the relationship management of "Born Global" entrepreneurs and unveils some negative impacts of social networks on the initiation of 'de-internationalisation'. The study reveals the importance of online social networks, high-tech communications and contemporary management techniques for "Born Global" entrepreneurs.
\end{abstract}

\section{INTRODUCTION}

Many managers and entrepreneurs, particularly in "knowledge intensive" firms, are seeking international business growth in a more proactive manner than before (Bell et al., 2004, Child and Hsieh, 2014). More and more firms are engaging in international operations in the early days of their establishment (Oviatt and McDougall, 1994, Bell., 1995, Knight and Cavusgil, 1996, Jones, 1999, Knight, 2000), They are the so-called "Born Globals" (Rennie, 1993, Knight and Cavusgil, 1996), "Global Start-ups" (Oviatt and McDougall, 1994), or "International New Ventures" (McDougall et al., 1994).

Since Small and Medium enterprises (SMEs) have limited resources and knowledge, and different managerial styles, the experience and knowledge gained from the study of large corporations cannot be directly adopted and utilized by their smaller counterparts (Calof and Beamish, 1995, Mejri and 
Umemoto, 2010); The main purpose of this research is to explore networking knowledge and experiences from "Born Global" entrepreneurs who are embedded in their social networks and relationships.

This paper examines the roles of social networks, one of the most important aspects of the internationalisation of SMEs(Styles et al., 2006). It investigates a "knowledge-intensive" rather than "traditional labour-intensive" firm. A small high-tech firm in the South East of England was selected because of the considerations of methods, time-scale, and resources.

The remainder of the chapter is structured as follow: Firstly, we review relevant literature, where we critically analyse the existing internationalisation theories and research activity in this field. Consequently, we develop the research problem. Secondly, we present the research objectives and research questions. Thirdly, we discuss the methodology. Fourthly, we analyse the data from the case company. We then move on to discuss the findings and, in the light of previous theories with the aim of constructing new frameworks for understanding the internationalisation of "Born Global" SMEs. Finally, we reflect on the importance as well as the limitations of this study and suggest an agenda for future research.

\section{LITERATURE REVIEW}

There are various definitions of internationalisation (Calof and Beamish, 1995, Liesch et al., 2014), one of the most common, by Benito and Welch being "the process of increasing involvement in international operations" (Benito and Welch, 1997). Since internationalisation is multifaceted, the subject has been addressed with differing perspectives and a variety of approaches have been used to study the phenomenon. The limitations of the economics-based approach are its over-simplification of the organizational decision-making process and the adoption of rational underpinning assumptions (Calof and Beamish, 1995). Behaviour-based process theories have been criticised as being too reactive (Autio and Sapienza, 2000) and over-orderly, like "rings in the water" (Madsen and Servais, 1997). They are inefficient in explaining the internationalisation of SMEs, particularly the "Born Global" phenomenon, which refers to a firm's engagement in international operations from the early days of its establishment (Jones, 1999, Rialp et al., 2005). Network-based theories, which consider the advantages of a network of relationships, provide more multilateral elements than their prior economic- and behaviour-based theories (Johanson and Vahlne, 2003), and can explain the different behaviour of SMEs, which is ignored by the previous approaches mentioned. Yet, as Axelsson \& Agndal (2000) point out, even such theories have not considered the importance of personal-level social networks (one's relations and contacts with others). Even in the limited literature about the influence of social networks on the internationalisation of SMEs, factors impeding internationalisation and the phenomenon of de-internationalisation have been ignored (Chetty. and Campbell-Hunt., 2004, Benito and Welch, 1997).

Current empirical studies about "Born Global" social networks have produced varied and often quite contradictory results due to over-reliance on quantitative methods (O' Donnell and Cummins, 1999, O'Donnell, 2014). These studies can be further divided into two main categories: those belonging to the rational perspective and those belonging to the embedded perspective. The rational perspective highlights a personal network as a lever which always provides additional resources, whereas the embedded perspective perceives the personal network as both a lever and a plug, as something the entrepreneur is embedded in for better or for worse (Klyver and Schott, 2003). Most of the existing studies adopt a rational perspective, such as for example, social relationships helping entrepreneurs minimize the risks and uncertainty of new markets (Ellis and Pecotich, 2001); social relationships can play a role as me- 
diators and door-openers to new international business relationships, i.e. introduce potential exporters to the international actors (Komulainen et al., 2006) etc. Therefore, a need to research entrepreneurial networking in the internationalisation of SMEs from an embedded perspective occurs. Previous network studies mostly seem to take a rational perspective. Social relationships are not only a "lever" that affords the entrepreneur with additional and useable resources for forthcoming activities (Klyver and Schott, 2003), but also a "plug" that makes start-up for internationalisation less viable. Thus, current propositions of driving forces, enablers and initiators will inevitably incur criticism and be challenged. Deinternationalisation refers to any voluntary or forced actions that reduce a firm's international activities (Benito and Welch, 1997, Vissak and Francioni, 2013). Previous study, such as Komulainen et al.(2006) has discovered the benign role of social networks at the beginning of internationalisation process. The literature, therefore, would benefit from more understanding into how social networks influence both the internationalisation and de-internationalisation of firms.

\section{RESEARCH OBJECTIVES AND QUESTIONS}

We intend to investigate the roles of the social network in initiating not only the internationalisation but also the de-internationalisation of a Born Global high-tech firm. This central research objective can be broken down into four sub-research questions as follows:

1. How do social networks influence an entrepreneur's introduction to potential international partners and business opportunities?

2. How do social networks influence an entrepreneur's information processes in acquiring potential international business partners?

3. How does an entrepreneur build his/her social networks in order to initiate the internationalisation/ de-internationalisation process?

4. How does an entrepreneur manage his/her social networks for the initiation of internationalisation/ de-internationalisation?

\section{METHODOLOGY}

Prior studies on SME networks focus on structural dimensions, such as size, range and density (Aldrich, 2001, Aldrich et al., 1989). However, studies in this area have mainly employed quantitative methods and provided little understanding of the content of network relationships. Case studies are suitable for addressing the "how and why" questions set up for the proposed research. For the study of relationship networks, case research, subjectivist or relativist approaches have been deemed as the best option (Easton, 1995). Coviello (2005, 2015) argues that case studies are particularly suitable for research that relates to networks, in the sense that, it helps generate insights into social dynamics and the operations of both the firms and the entrepreneurs over time.

Stenbacka (2001) and Yin (2003) argue that small size, inductive approach and case study strategy may achieve more analytical or theoretical generalization rather than statistical or population generalization for a deeper understanding of people's behaviour and motivations. The selection of an appropriate case helps to define the limits for generalising the findings. Based on this suggestion, a "Born Global" small 
firm in the South East England was selected. The case firm, IA's business activities were international in nature. It was founded as an internationalisation accelerator to help other companies internationalize their business. Because it is rare, a phenomenological approach is considered the most appropriate.

Data collection involved interviews, analysis of company documentation, and consultation of public databases, and researcher observation. Three stages of data collection have been deployed as showed in Table 1.

Although the study firm, from here on to be called 'IA', is a small sized company, its management team has sophisticated international business experience, a sound educational background, a wealth of professional knowledge, and experience of working for big corporations. They have extensive company documents and records which include business plans, management diaries, memos, and minutes of meetings. They also have a web page displaying information in both Chinese and English languages. The present study adopted personal interviews to collect primary data. The research procedure involved a series of interviews; an initial open-ended face-to-face interview, a second telephone and online reinterview and a feedback interview. The personal, face-to-face interviews gave the opportunity to the researcher to probe if anything should be unclear or require further discussion (Zikmund, 1994). The semi-structure interview addressed the research problem themes and helped explore new issues during the study (Saunders, 2011). Telephone and online instant message conversations were used to explore hitherto unexplored and underexplored and newly identified questions which emerged following the initial interviews. This was very useful in supporting the data collection in the instances where participants could not be available for data validation and feedback.

The analyses of case study evidence followed the initial literature review, identification of research gaps and the development of research questions. This analytic strategy helped to ignore weak or spurious data to focus attention on relevant data. It is expected that such a process of analyses could help to generate useful findings that would contribute to in-depth understanding and reliable theory development. In order to improve the validity of this study, the chapter describes the study firm's context in detail to ensure more clarity. Credibility was also enhanced through the supply of relevant information to participants before interviews. Individual interviews, discussion, and document analyses in parallel

\section{Table 1. The procedure and contents of data collection/analysis}

\begin{tabular}{|c|c|c|c|}
\hline Stage \& Purpose & Primary Data & Informant \& Outcomes & Secondary Data \\
\hline $\begin{array}{l}\text { 1. Introduction \& } \\
\text { informant consents }\end{array}$ & Initial telephone interview & $\begin{array}{l}\text { The Entrepreneur (gained an } \\
\text { initial picture of the case firms and } \\
\text { prepared information for further } \\
\text { interviews) }\end{array}$ & Data from FAME, \\
\hline \multirow[t]{2}{*}{ 2. Interviews } & $\begin{array}{l}\text { a) Face to face interview } \\
\text { b) Business plans, management } \\
\text { dairies, transaction records and } \\
\text { minutes of meetings }\end{array}$ & $\begin{array}{l}\text { The entrepreneur (provided } \\
\text { information from his perspective) }\end{array}$ & $\begin{array}{l}\text { Company websites and press } \\
\text { releases }\end{array}$ \\
\hline & $\begin{array}{l}\text { Online interview via MSN online } \\
\text { interview }\end{array}$ & The entrepreneur and his family & \\
\hline \multirow{2}{*}{$\begin{array}{l}\text { 3. Follow up } \\
\text { information seeking } \\
\text { and Validity checking }\end{array}$} & MSN online interview & The entrepreneur & \\
\hline & $\begin{array}{l}\text { a)Feedback interview } \\
\text { b)Company research reports and } \\
\text { clients' profiles }\end{array}$ & The entrepreneur and his family & \\
\hline
\end{tabular}

Note: With the participants' consent, interviews were digitally recorded and later transcribed and analysed. 
have been used as a form of methodological triangulation. The main researcher was able to speak both Chinese and English and could, therefore, check the validity of primary and secondary data collections from Chinese and English-based sources. Several discussions about the analyses and results were conducted with the contact persons in order to verify or refute findings, and different investigators have reviewed the draft chapter.

An interview diary was kept, and the use of digital document folder was incorporated in the protocol and served as a database (Yin 2003). At the outset of this study, the researchers emphasized the importance of maintaining confidentiality of the discussions and protecting the anonymity of respondents throughout. The interview took place in the university meeting room and a Chinese office making the atmosphere open, warm and friendly. The study invited an assistant, second interviewer to act as an external investigator during data collection and analysis process so that any misunderstanding or misinterpretation of language would be minimized.

\section{THE CASE STUDY}

\section{The Case Firm}

IA is a high-tech business service firm. IA's business concept was generated in 2002. At that time, the entrepreneur identified that there was no "market acceleration" service which provides small information and communication technology (ICT) companies in the UK to accelerate their internationalisation into the Asian market.

According to IA's business plan, the vision of the business was to become known as the leading Asian market entry specialist for Western ICT companies within five years. Its mission was to provide costeffective and accelerated market entry capabilities to its clients. IA helps clients to raise profile, build up sales channels and generate revenue. The company's unique selling proposition (USP) is to help its clients generate fast revenue from the Asian market whilst limiting their risk, costs and uncertainties, during the process of internationalisation.

IA provided four types of services as indicated below:

1. Market Research: Before small ICT companies enter the Asian market, IA will help them to perform a viability test which identifies chances of success. It can provide information such as existing demand, channel players, competition, product substitutes, other local requirements and the level of investment needed to launch and support products/services. IA also uses its networks to advise clients on how to select local partners including joint-venture partners, distributors, value-added resellers, and software developers or service providers.

2. Marketing Services: These small ICT firms may have insufficient capabilities to promote their products and services. Therefore, IA can provide marketing services for presenting their companies to Asian audiences in local languages and in a way which is effective in the target market. These marketing services include translation of manuals, user interfaces, websites and documentation, presentations, press releases, web marketing including web site design, search engine optimisation, newsletters, email campaigns, event management, public relations, product launches. 
3. Sales Services: IA can operate as its clients' local sales contact in their selected market. It can adopt either a direct sales approach or provide support for the selection, appointment and management of partners. The sales services include selecting and appointing distributors, resellers and service providers, identifying and negotiating with joint-venture partners, conducting end-user sales programme, telesales programme, training programme, product demonstrations, and pre-sales consultancy.

4. Representation: IA is also able to take responsibility for its clients' business in China by providing a comprehensive and fully managed sales, marketing and technical support operation, effectively becoming their branch offices. By doing so, IA will help their clients to establish their market position faster. IA is willing to share its virtual office in China (VoiC) with its clients. This service provides its clients with a Beijing office address which they can put on their websites. It provides them with Chinese web pages which are optimised for Chinese search engines. It handles enquiries on their behalf in Chinese and writes a summary of each enquiry in English for clients to respond to if they wish to.

\section{EVOLUTION OF RELATIONSHIPS DURING INTERNATIONALISATION.}

\section{The Relationships with Internal Business Partners}

In 2002, the entrepreneur, hereon called Mr. EB developed the business concept for IA and discussed this with his former subordinate, hereon called Mr. BH in Beijing China. They both agreed that this high-tech ICT "market acceleration" service would have a great potential for international China-UK high-tech businesses. Their social relationship was the main component of the formation of the company. However, like every new partnership, there were initial conflicts and disagreements which had caused some serious problems for the further development of the company.

Another business partner, Mr. S was a distributor for company CR, Mr. EB's former employer. He had over 20 years working experience in selling IT products and solutions to large Indonesian, Singaporean and Malaysia organizations such as government departments and banks. At the time of the study, he was an associate of IA in South East Asia. He contacted Mr. EB in a proactive manner and they were setting up a new subsidiary company for IA in Singapore.

\section{The Relationships with Clients}

IA currently has two kinds of clients; (1) direct clients (paying clients) who pay for IA services and commission based clients who are only willing to pay IA an agreed percentage of sales revenue.

IA currently had three commission based clients: $\mathrm{T}$, a British electronic transaction service company and $\mathrm{B}$, a British designer and manufacturer of landline and wireless telephone equipment and $\mathrm{A}$, an American Instant Messaging (IM) technology company. IA's two direct clients include R, an American software specialist for university accommodation and conference service management and F, a software company providing electronic document solutions. 
In the business relationships above, the most important one in terms of revenue was the relationship with company R. Mr. EB met R's sales director Mr. Cr. on Europe's foremost global online networking platform, www.openbc.com. At that time, they did not know about either one's business; they talked about computer technology problems on the Bulletin Board Service (BBS) forum openly. They also talked about personal interests such as golf and travel. In August 2004, they discovered that they would both attend the same exhibition in Bangalore, India and arranged a meeting. The first time they met each other face-to-face was at the end of 2004. The sales director Mr. Cr. was very happy to introduce Mr. EB to the CEO of the company R. they had dinner together after that introduction. When Mr. Cr. and the CEO of $\mathrm{R}$ visited London, Mr. EB picked them up at the airport and treated them sequentially. Mr. EB elaborated on the potential business opportunities in China. After a couple of follow up conversations and discussions, they formulated a five stage strategic plan from market research to product launch and sales in China.

Mr. EB met A's CEO Ca. in the Infosec exhibition at London's Olympia, which is Europe's Internet \& Network Security show which features over 200 exhibitors from around the world. Before Mr. EB visited the exhibition, he identified some fast growing ICT companies which had not exploited the Chinese market. He did this by browsing their web pages and making some cold calls to make further enquiries. Following that, he successfully built up business contacts with the CEO of company A and formed and signed a co-operation framework agreement. Mr. EB's commented on his relationships with $\mathrm{Ca}$ that: "The relationship is still very 'matter of fact'. He seems just interested only in talking about business and keep the relationship shortly within a planned agenda. We had short conversations and meetings since that first meeting in London. I had only spent one evening with Cr. having dinner at an Indian restaurant near the airport. I sometimes find this style difficult."

Mr EB was still employed at his previous place of work when he started his business and only ended his life as an employee when he realised the full potential of his business and the fact that he needed full attention for his own business. The other three clients are the current or former customers of Mr. EB's previous employer. According to Mr. EB, he thinks that these relationships are business orientated rather than social orientated. "I have to be partial to my [previous] boss' clients. I cannot push them, sometimes these relationships are my burdens because I am unwilling to let my [previous] boss know that I am doing business with his clients. Actually, none of them is my major clients now."

\section{The Relationships with Local Partners}

IA's external partners in China include the potential dealers, distributors, original equipment manufacturers (OEM), outsourcing and licensing partners, buyers, software testing, localization co-operators etc.

BH's social relationships are playing a main role in the business development process. For example, one of his friends Lz, the owner of the company, offered to share office space for free and also introduced some potential business partners to IA. One of these partners is a well-known software outsourcing company. BH's social networks also helped IA to bring some potential partners in the Beijing region. However, BH's social networks have some regional restriction because most of his contact people are mainly in Beijing and North East China. Occasionally, Mr. EB suggested potential contacts that might bring some useful information for IA. BH seemed uncomfortable to contact people outside his existing contacts and networks. In addition, some of his friends, e.g. Lz, in his social networks had caused some trouble for IA cooperation with other companies. 
In other parts of the Asian market, Mr EB's social networks have also reached India, Singapore, Korea and Japan. These social networks provide local contacts and business information for IA. The most significant social relationship is Mr. JPH, the vice president of a Korean distributor. Mr EB has a good relationship with Mr. JPH. Every time Mr. EB visits Korea, they had dinner and Karaoke together. In return, Mr. EB also entertained Mr. JPH and his wife quite a few times while they visited Singapore. When Mr. JPH's daughter came to the UK to study at a London university Mr. EB helped her many times. Therefore, Mr. JPH became an important family friend of Mr. EB. Mr. JPH had also helped Mr EB a couple of times to check up on IA's potential business partners and had helped to prevent some potential cheats.

\section{The Relationships with Common Interest Groups and Professional Service Providers}

Mr. EB's accountant Pa helped IA not only to perform the company's registration but to also advise on international tax issues, shareholder's agreements, the annual accounts etc. Mr. EB's solicitor Ps helps IA look after their intellectual property rights (IPR), company strategy, and international business contact issues and so on.

Also, IA benefits from Mr. EB's relationships with his friends in the European market acceleration business and in his consultant networks, www.abcol.com and internet common interest group association, www.linkedin.com and www.openbc.com. "I need to meet new people because my existing social networks do not always have the experience and knowledge of international business."

\section{THE SOCIAL RELATIONSHIPS EVOLUTION PROCESS}

\section{The Establishment of Social Relationships}

The present analysis is based on Ellis (2000)'s classifications of origins of business relationships: planned networking, business-social networking and non-business social relationships. As an entrepreneur of a "Born Global" firm, Mr. EB has built up his social networks through different approaches. The most common way to originate social relationships for the case entrepreneur is through activities related to his work. His relationships with former colleagues, clients, distributors are the main sources for his social networks. Another popular way to build up his relationships with people is through attending exhibitions and conferences, for example, Infosec, London; IT.com conference, Bangalore, India. Mr EB has also developed his relationships with people through some business events, for example, his relationships with the Russia businessman Ir was built up in one Chamber of Commerce London Event. This relationship actually provides our case entrepreneur with emotional and commercial support for IA's development. In addition, he builds up social relationships with people on some internet chat rooms and professional BBS forums, such as www.openbc.com, www.linkedin.com and www.abcol.com. Also, he benefited from his position in his previous immediate employment which provided him with the opportunity to select some potential clients from his employers' client base. In the case study, only the relationship with one client, company A, was built up through a planned cold-call. Important relationships were generated after leaving employment to focus fully on IA and its internationalization. 


\begin{tabular}{|c|c|c|c|c|c|c|c|}
\hline 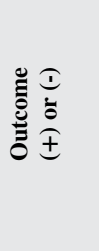 & 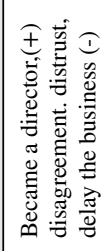 & 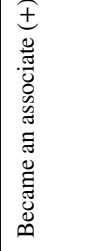 & 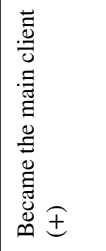 & 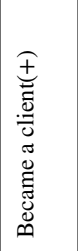 & 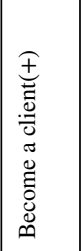 & 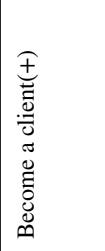 & 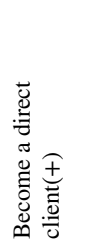 \\
\hline 产 & 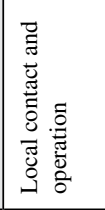 & 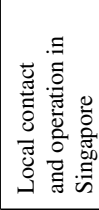 & 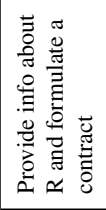 & 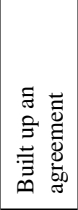 & 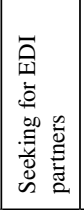 & 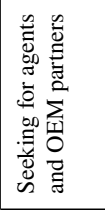 & 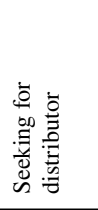 \\
\hline 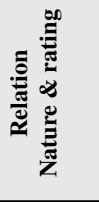 & 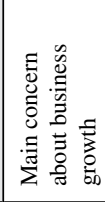 & 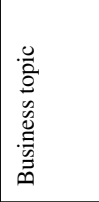 & 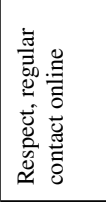 & 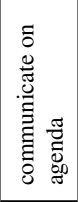 & 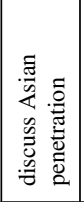 & 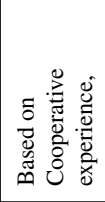 & 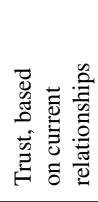 \\
\hline 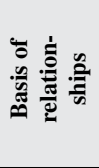 & 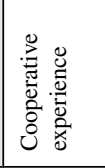 & 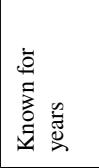 & 耪 & 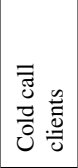 & 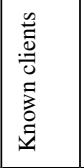 & 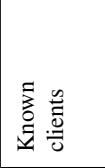 & 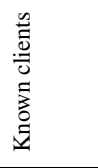 \\
\hline 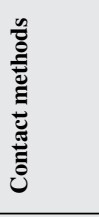 & 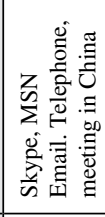 & $\begin{array}{l}z \\
z \\
\sum^{n} \\
\overline{\tilde{I}} \\
\text { 至 }\end{array}$ & 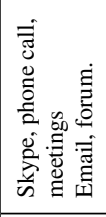 & 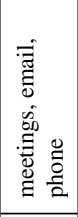 & 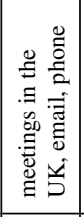 & 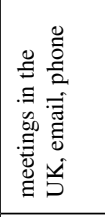 & 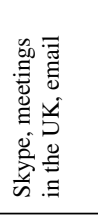 \\
\hline 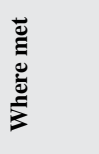 & 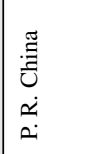 & 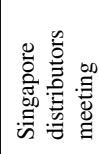 & 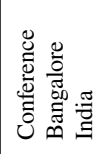 & 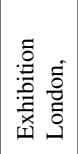 & 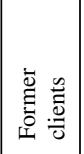 & 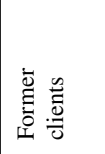 & 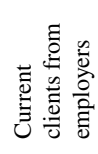 \\
\hline 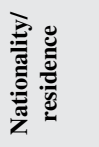 & 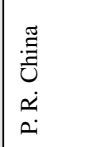 & 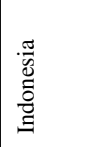 & 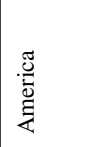 & 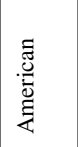 & 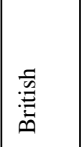 & 童 & 部 \\
\hline 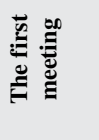 & 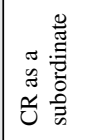 & 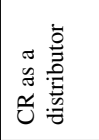 & $\begin{array}{l}\stackrel{\Xi}{\Xi} \\
\stackrel{\Xi}{\Xi} \\
. \Xi\end{array}$ & 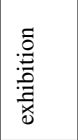 & 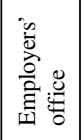 & 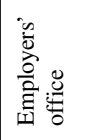 & 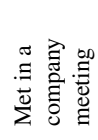 \\
\hline 言 & 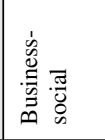 & 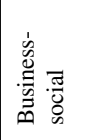 & 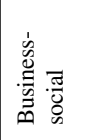 & $\begin{array}{l}\text { 总 } \\
\text { 言 } \\
\text { 品 }\end{array}$ & 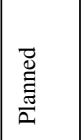 & 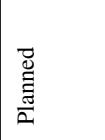 & 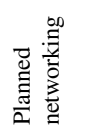 \\
\hline$\stackrel{\mathscr{\sharp}}{4}$ & $r$ & 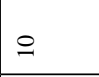 & $\mathrm{a}$ & 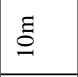 & $\mathrm{N}$ & m & - \\
\hline 彥 & 存 & in & $\stackrel{\Perp}{\stackrel{\sim}{*}}$ & త్ తే & 5 & है & 窇 \\
\hline 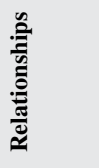 & \multicolumn{2}{|l|}{ 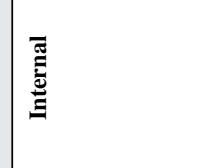 } & \multicolumn{5}{|l|}{ 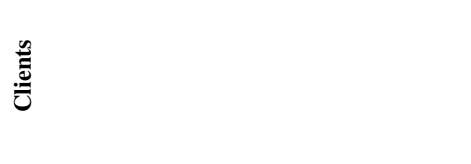 } \\
\hline
\end{tabular}




\begin{tabular}{|c|c|c|c|c|c|c|c|}
\hline 产 & 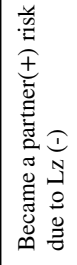 & 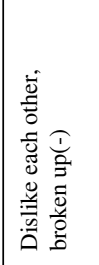 & 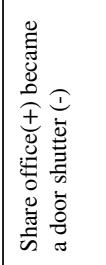 & 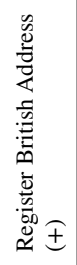 & 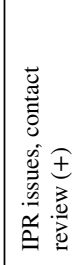 & 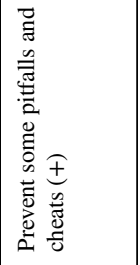 & 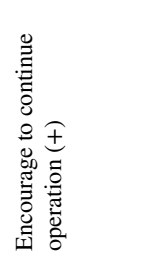 \\
\hline 常 & 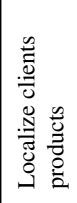 & 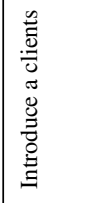 & 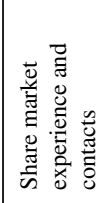 & 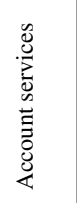 & 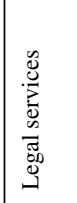 & 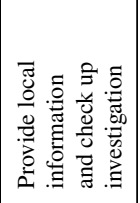 & 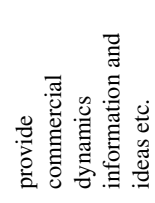 \\
\hline 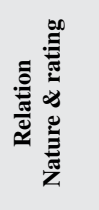 & 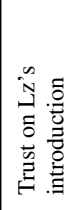 & 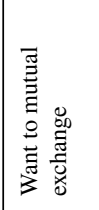 & 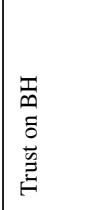 & 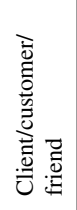 & 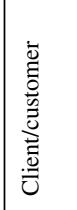 & 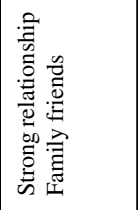 & 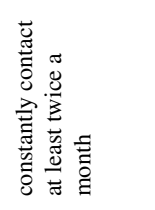 \\
\hline 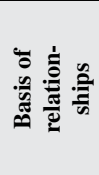 & 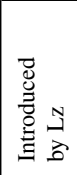 & 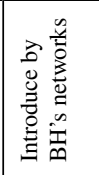 & 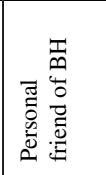 & 总总 & 壳题 & 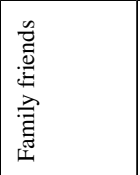 & 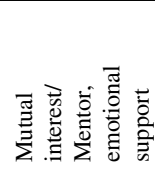 \\
\hline 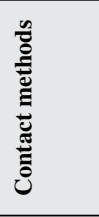 & 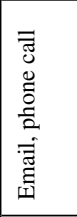 & 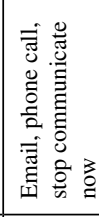 & : & 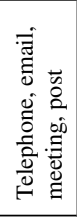 & 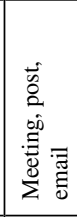 & 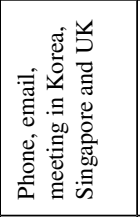 & 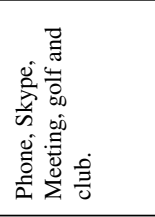 \\
\hline 离 & 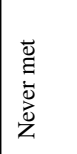 & 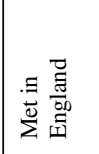 & 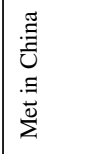 & 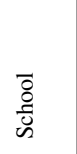 & 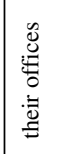 & 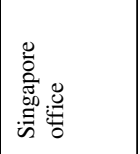 & 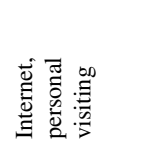 \\
\hline 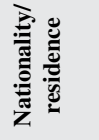 & 莺 & 苞 & 苟 & 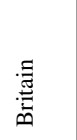 & 苞 & 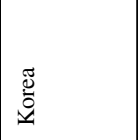 & 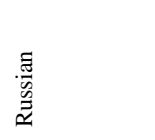 \\
\hline 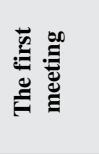 & 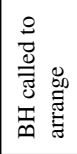 & 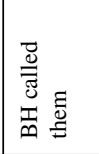 & 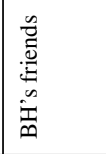 & $\begin{array}{l}\overrightarrow{0} \\
\text { 离 } \\
\end{array}$ & 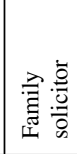 & 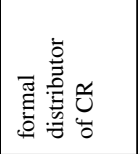 & 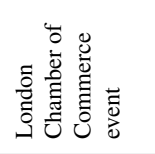 \\
\hline 莺 & 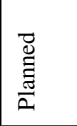 & 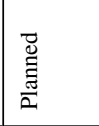 & 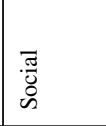 & 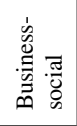 & 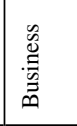 & 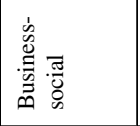 & 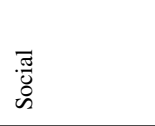 \\
\hline$\underset{4}{4}$ & $\underset{f}{\Xi}$ & $\underset{m}{a}$ & $\Xi$ & i & $\sim$ & $\infty$ & + \\
\hline 产 & Ш & ְ. & $\cong$ & 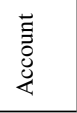 & 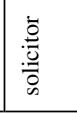 & 胥 & $\Xi \stackrel{x}{x}_{m}^{x}$ \\
\hline 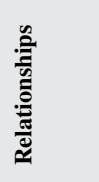 & \multicolumn{3}{|l|}{ 苞 } & \multicolumn{2}{|l|}{ 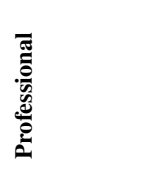 } & \multicolumn{2}{|l|}{ 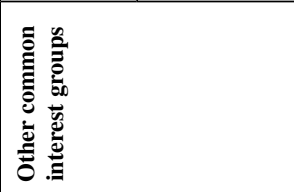 } \\
\hline
\end{tabular}




\section{The Maintenance and Transformation of Social Relationships}

For the case entrepreneur, the most popular methods used to contact his social networks is through the internet, i.e. email, Skype ${ }^{1}, \mathrm{MSN}^{2}$, ICQ ${ }^{3}$. He also manages his social network data by using some software programmes and a customer relationship management (CRM) system, which helps him to record and categorize his social contacts, to remind him of the time and location when they first met, the main contents of the last conversation, people's birthdays, wives and kids' names and so on. He admits that he will probably contact these people at least once every two months by telephone. Occasionally, he will contact people such as accountants and solicitors through post due to some original paperwork that cannot be done through electronic documents. Moreover, he takes business trips to visit his existing or potential business clients and partners frequently.

The value of Mr. EB's relationships is to provide his clients with contacts in his networks for new markets. For instance, European colleagues Ir helped IA reconstruct its business concept and operational models. The relationships with different Asian countries led to his ambitions to set up subsidiaries in those countries. Some of his business relationships had been transformed into family friends, for example, Mr. JPH. Some pure social friendships, for example, the online social relationships with Cr had become a business-social relationship. "Actually, I don't really make a distinction between social, personal and business exchange relationships. I am a social person and tend to treat everybody as a friend." Most of the important people in his networks with respect to the internationalization process have ICT market knowledge. He had some comments on relationships with people who come from different countries, for example, he thinks that many American businessmen tend to keep their relationships purely business orientated.

\section{The Enhancement and Impairment of Social Relationships}

Not all of Mr. EB's relationships could go further. It requires the efforts from both sides. According to the interviews, Mr. EB's relationship with his business partner BH was impaired because of some disagreements and distrust. This actually caused de-internationalization (Chetty 1999, Benito \& Welch, 1997). "Maybe BH does not want other people to know that he is doing our business. I asked him to host our company webpage in China to optimize Chinese search engines. It took ages for him to respond and he has not finished until now."

Another example, when $\mathrm{BH}$ was looking for a distributor for the company $\mathrm{F}$ in China, one of his friends, Mr. Lb, introduced a potential customer to IA. However, Lb asked our case entrepreneur to help his son to get a job in London which is difficult to do because of various reasons. The social relationships had been impaired after Lb realized that Mr. EB was unable to help. On the contrary, some relationships have been enhanced due to the frequent communication, for example, Mr. S is going to set up an IA subsidiary in Singapore soon. "I need to prepare incentives to stimulate some of my relationships, and I also need to understand when and how I have to stop my relationships with what kinds of people. Otherwise, it will influence my business"

\section{Information about International Business Opportunities}

From Table 2 it is evident that social networks play roles as "lever" and "plug" in facilitating the access to international business opportunities. An illustrative quote from our case entrepreneur suggests that: 
"I have experienced some strong criticisms from my social networks in the identification and evaluation of international opportunities, particularly for some complicated, brand new, innovative ideas when I communicated to people in my social networks that lack similar knowledge and which are outside their experience. It is difficult to make them understand the business opportunity; what do we want, and what is the opportunity. They bring some wrong information when we were evaluating the opportunities. For instance, when we discussed the business concepts of $\mathrm{T}$ who provides electronic transaction through its web page service rather than traditional software, $\mathrm{BH}$ was unable to understand what kind of opportunities there are. He brought some wrong market information; wasted time and money and almost lost this contact. In my case, a lot of business opportunities cannot be delivered due to the limitations of my existing social networks."

However, not all these criticisms have negative results. Some of the criticisms helped IA reconstruct its business model to reassign resources and also modify targets:

"When we first started up our business, we contacted a lot of clients who are commission based only. I thought that they should be my main concern and clients. I talked to Ir who is doing a similar market acceleration business in European... He criticized my business concepts and commented that it is the worst thing for a market acceleration company. If I do so, you must be mad or desperate. I disagreed with them for a while. Finally, it had been proven that it is true. It wasted a lot of my time and efforts to do the pre-internationalization research for my clients without any returns. Now I am targeting more on some well-funded companies with great growth potential and did not consider entering the Asian market yet. They would like to pay for my service directly. After my conversation with Or, I understand how to present ourselves to potential clients. How to show them some baits; show them that they need to pay IA to get things done; show them some 'real opportunities' e.g. some profitable potential customers in the Asia market. Make thing happen is what our organization want. It took me a long time to reach this stage. Without the criticism from my social networks, it might have taken even longer."

\section{Information about International Business Partners}

The most important relationship for IA is the one between the co-directors. At the time of the study, the relationship between Mr. EB and Mr. BH was deteriorating. Some disagreements, complaints and doubt emerged and the company was in a crisis. Mr. BH was not only Mr. EB's subordinate but also his personal friend. They had a close and trusting friendship, however, this close relationship had been changed since they formed IA with equal joint ownership and directorship. EB chose BH as his Chinese partner only because he had worked with BH for a long time and assumed that the friendship would translate into a good business partnership.

However, EB discovered that BH lacked the required transparency, honesty and commitment to make the business partnership work. For example, he found out that BH was involved in some projects with other people. In the process of delivering IA's project, BH did not finish what he said he would do. He was unwilling to work full time for IA even though EB would like to pay him a higher salary. In addition, although EB wanted to conduct the in a transparent and open manner, there were some suspicious financial expenditure issues from the side of $\mathrm{BH}$. The situation therefore led to disagreements. Although IA China Ltd had been registered in the UK, it had not been registered as a formal company in China because BH did not want to pay tax and administrative fees to the Chinese Authorities. In addition, BH's job commitment and performance were below what was expected. For example, when EB was taking a vacation, his mobile messaging, which was connected to his email mailbox showed that there was an 
important inquiry which came from an important client, company R. Then, he reminded BH by email and asked for a response. When EB came back to England from the holiday, BH was yet to deal with the inquiry and a phone call to him at the time showed that he was sleeping on the job at 3:00pm local time.

Such complete disregard to clients and poor attitude to work led to the erosion of confidence. This led to EB considering the option of ending the partnership to seek a new partner who would be more qualified and committed to setting up subsidiaries in other Asian countries. EB argued that: "Social relationships can provide me with an easy way to find business partners. However, it is not always the case. We need to consider whether these potential partners have the capabilities to help you develop your business. Are they the best ones for you?" This led to EB to conclude that entrepreneurs cannot over-rely on their social relationships in seeking international business partners. They needed to develop the profiles of their prospective partners by researching extensively on their suitability. For example, resources, knowledge, experience, reputation, capability, complementary information etc. are important if the partner is to help the business succeed and grow.

\section{Introduction to Potential International Partners}

The establishment of IA China Ltd's Beijing office thanks to BH's social relationship with his friend Lz, an entrepreneur who had an office in Zhong GuanCun Industry Park. Lz shared his office with IA without charging a fee. BH kept a very close personal relationship with Lz. Through Lz's introduction, IA was able to increase contacts, for example, Ensemble, an important Beijing software company providing software testing and localization services. However, after the 2006 Chinese New Year, there were some financial conflicts between Lz and Ensemble. Due to BH's close social relationships with this friend, Ensemble tried to disengage the co-operation with IA. "Guanxi" in China plays a vital role between business partners. $\mathrm{BH}$ and our case entrepreneur attempted to explain and appeal to the CEO of Ensemble that Lz is not a shareholder of IA's business. They had to go virtually rebuild the relationship. They had to spend a lot of money and time, for example, buying dinners and gifts for the CEO's wife etc. The situation with rebuilding the relationship with Ensemble delayed the implementation of their strategic plan.

\section{ANALYSIS AND DISCUSSION}

\section{The Answers of the Research Questions}

1. Building Social Networks: On the initiation of internationalization, an entrepreneur can utilize both "relationship sediments" that date from a number of years back (Axelsson and Agndal, 2000) as well as some new networks, which have been built up more recently. The entrepreneur of the case firm had built up his relationships with people who are important for the internationalization process through various ways. Personal relationships and contacts generated from his previous place of work, whilst some specific preference were given to selecting people who have worked with him and have similar industry backgrounds. Marketing events, such as exhibitions or Chamber of Commerce activities are usually a starting point for developing networks and building relationships. Online social networks are other important resources for developing networks. Developing online relationships are important for supplementing other approaches to building social relation- 
ships. This finding supports earlier research results related to building online social relationships (Cummings et al., 2002). Anderson and Jack's (2002) findings also show that social relationships and social capital development are not only based on commercial transactions but can also be built and/or maintained through a variety of forms of online relationships.

2. Management of Social Networks for the Internationalisation Process: The case entrepreneur relied on his solid educational and technical background to dictate preference and use of technical software programmes such as personal information management and customer relationships management (CRM) systems to manage complicated social networks. In order to overcome some barriers such as time difference and expenditure on telecommunication fees, the reliance of the information and communications technologies such as the use of Internet Instant Message services can reduce cost whilst at the same time enhancing customer satisfaction. Maintaining frequent contact with existing and potential contacts would bring more value to organisations. In the networks management process, some business-orientated relationships have been changed to personal socially orientated ones. Development and interaction of social relationships is an ongoing process and not necessarily a purposeful act (Jack and Anderson 2002) and this can, of course, have benefits, as well as disadvantages. The relationships between the entrepreneur and his clients can prove that social relationship enhancement, on the one hand, increases entrepreneurship and initiates the internationalization. On the other hand, impaired relationships with previous clients could be deemed as an initiator of de-internationalization. Existing literature has not adequately highlighted the effect of impaired relationships on de-internationalisation.

3. Social Networks, Information Acquisition and International Business Opportunity: The case entrepreneur's social networks bring business opportunities from his current clients, as well as from online social networks, a finding which is consistent with previous studies by Ellis and Pecotich (2001) and Komulainen et al (2004). Some New Venture Internationalisation (NVI) theories (Oviatt and McDougall, 1994) suggest "Born Globals" have the capabilities to seize the cross-border opportunities unseen by competitors, which fits the case company. This empirical data also supports Holmlund and Kock's (1998) findings that personal contacts initiate internationalization. However, the empirical data from the interview has also pointed out the barriers and criticisms from the entrepreneur's social networks. These barriers and criticisms also have both positive and negative results, as already identified in previous literature (Klyver and Schott 2003). For "Born Global" firms in the high-tech sector, firm innovativeness enhances business opportunities; however, the opportunities in the sector are often complex and not easily understood. Therefore, only a limited number of the members of entrepreneurs' narrow social networks would have the requisite knowledge and experience to perceive such opportunities. In the case study, friendships between the entrepreneur and a Russian counterpart in a similar business who is actually playing a mentor's role in IA benefited the latter in terms of the business opportunity identification and evaluation processes. This also agrees with Mainela's (2002) previous study of the importance of friendships and social relationships in the internationalization.

4. Social Networks, Information Acquisition and Potential International Business Partners: Social networks of an entrepreneur are made up of personal trust, mutual sympathy, and confidence (Komulainen et al., 2004, Komulainen et al., 2006). In the case study, these relationships can be both enhanced and impaired and this depends on the balance between exchange and expectation. Having the co-entrepreneur as a partner and utilizing his social networks is one of the most important elements to access foreign business networks. This can be interpreted using theoretical frameworks 
such as Crick and Jones's (Crick and Jones, 2000) contacts pattern and Johanson and Vahlne's (2003) individual level psychic distance. In creating the entrepreneurial venture, the entrepreneur of IA selected the co-entrepreneur as a partner because they had known and worked with each other for years. These are the opinions that had been studied by some scholars previously (Holmlund and Kock, 1998, Ellis, 2000). Previous studies emphasized that uncertainties and risks of internationalization could be minimized by social relationships (Ellis and Pecotich, 2001). However, the case entrepreneur had occasionally regretted his selection of partners from his network of social relationships. On the contrary, he thinks that this is the riskiest thing. "If he is an employee I can fire him, but if he is already my friend, it will be very difficult to get rid of them." He thinks that entrepreneurs should always be realistic about the challenges involved in determining how a business partner is selected.

5. Social Networks and Introduction to Potential International Partners: Komulainen et al (2006) point out that social relationships can mediate or open doors to new business relationships, i.e. introduce the potential exporter to the international actor. However, in our case study, the coentrepreneur's friend (a referee) had quite an opposite effect, i.e. that of being a 'door shutter' for IA to an important localization partner. At the beginning, when their relationship was still harmonious, the references provided for IA increased. However, when this referee's reputation declined and the relationship with the localization partner was damaged, the relationship between IA and the localization partner also deteriorated. Thus, damage to the reputation of the profile of the referee in local business networks decreased the initial credibility and legitimacy within a market.

\section{FINDINGS FROM THE CASE STUDY}

\section{The Other Side of Social Networks: Internationalization and De-Internationalization}

The present study has identified a weakness in the research of internationalization of the firm and notes that absence of adequate de-internationalization literature. Although scholars had already observed this phenomenon (Chetty, 1999, Benito and Welch, 1997, Calof and Beamish, 1995), however, the reasons and causes of this phenomenon have not been studied in depth yet. In the case study, the impairment of social relationships seems to be playing an important role in the process. A research proposal of social influence of de-internationalization may have a prosperous future.

Another finding of social relationships in the internationalization is its negative effects for the "Born Global" SMEs. As already mentioned, current literature emphasizes the positive benefits generated by social networks towards internationalization performance. Particularly in high-tech sectors, people in social networks might misunderstand high-tech international opportunities and thereby end up providing inaccurate market information. People within social networks might not be qualified to be business partners. Without careful scrutiny, forming partnerships with members of social networks could adversely affect a business when challenges arise. In particular, challenges related to trust between partners and the lack of motivation that may arise from a partner can easily throw the company into crises. In addition, the damage of relationships with a low profile or bad reputation local partner can also damage the credibility, reputation and legitimacy of a company which could lead to suspicions or bias from 
potential international business partners. The ongoing relationships between references and the people they introduce to entrepreneurs have a very strong impact on all parties. In sum, the negative impacts from social networks will lead to the initiation of de-internationalization. Figure 1 shows a new framework adapted from Komulainen et al (2006) on the influence of the social network in the start-up of the internationalization from an embedded perspective.

\section{Managing Relationships in the Internationalisation of Small 'Born Global' Firms}

In high-tech sectors, quite a few international businessmen will normally have both good marketing education and high-tech knowledge background. These might be the starting point for the outwardmindedness of the "Born Global" entrepreneurs (Crick and Jones, 2000). These people have their own social networks and preferred ways of making friends and getting along with other people. In the case study, some internet communication tools have been adopted by these high-tech people for a long while. Some software programmes have been used to deal with the complicated social relationships from different countries and different industries. However, current literature does not throw adequate light on the influence of networks and relationships on the internationalization small "Born Global" high-tech firms.

\section{The Importance of Internet and Online Relationships}

The importance of the online relationship for entrepreneur of "Born Globals" firms is revealed in the case study that suggests that online relationships developed into social oriented as well as business-oriented relationships which encouraged cooperation and the establishment of a strong and lasting business

Figure 1. The social network influence in the initial internationalisation from an embedded perspective Notes: developed and integrated with Komulainen et al (2006)'s model

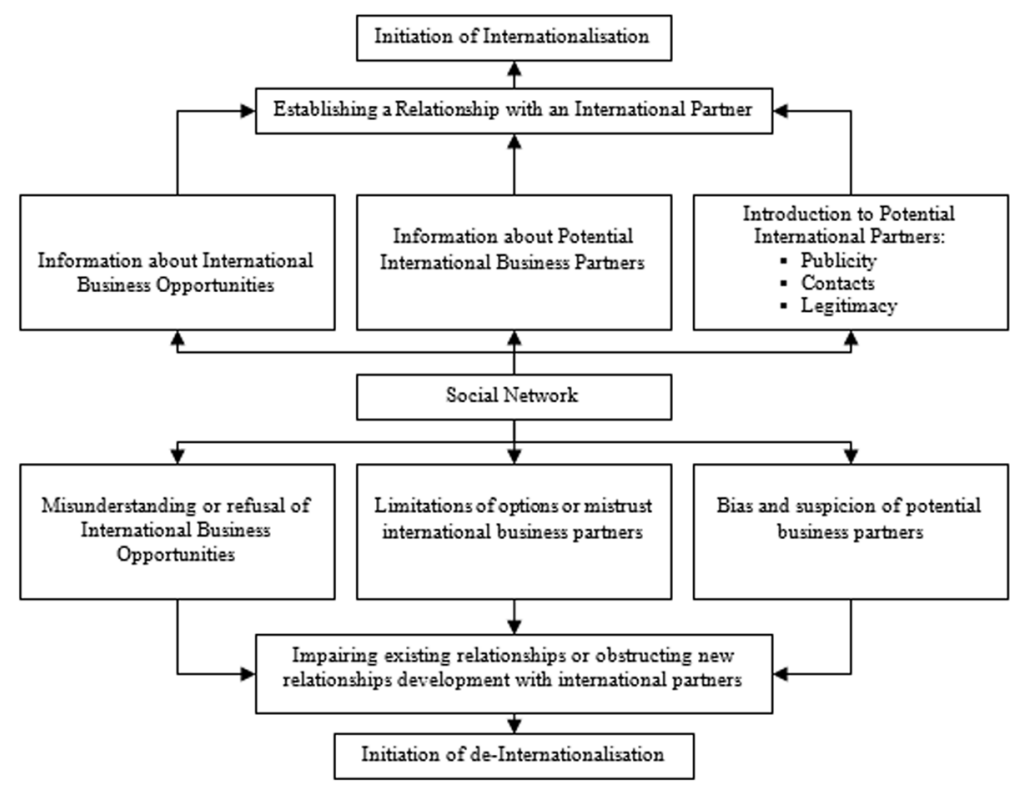


relationship. Consequently, online relationships might actually supplement or substitute existing social relationships to help "Born Globals" firms to overcome the limitations of existing social networks.

\section{PRACTICAL PROBLEMS}

The relationship problem between co-directors is the biggest drawback. Although the case company was registered as a private limited company, its operation is more like a partnership. There are some control problems within the company because of the equal share of the business partners. For the studied company, the communication between two partners is not transparent because they began to distrust each other and the partners were not adequately transparent with their activities within and outside the company. Without trust and the free flow of information between partners maintaining social networks and business contacts with both local and international clients become more challenging. This occurs because the partner, without the benefit of full information, may not understand the needs and business concepts of existing and potential clients adequately. This could, inadvertently, lead to loss of business opportunities. It is therefore extremely important that partners communicate effectively about the needs of their clients to ensure that the absence of one partner could not lead to loss of important business contacts or potential business.

\section{LIMITATIONS}

Although our study reveals new perspectives on the impact of social networks on "Born Global" firms, with a specific focus on the high-tech SMEs we note that there are areas of the study that could be strengthened to improve our understanding of the phenomenon under study. The findings of the current study have some notable limitations: First of all, the research is based on a single firm case study and opens the findings to well-known limitations of case study research. The rigor of case study research is one of the main concerns (Yin, 2003). Some equivocal evidence or biased views might also influence the direction of the findings and conclusions (Yin, 2003). This is a single case study to explore the social relationship in the initial start-up of internationalization for a "Born Global" high-tech firm in ICT sector. The findings may not necessarily work in other contexts, for example, other industries, non-Chinese markets, and traditional manufacturing firms. Our inability to check responses with other interviewees limits the strength of some of the findings. The study could not do so because the interviewee of the case company suggested that the researcher should not approach other respondents and informants outsides his company due to privacy, trade secrets and business etiquette issues. This means our current study is deficient in being able to provide sufficient variance and data triangulation as suggested by Yin (2003). There are also limited available public secondary data of the case company that could provide additional supporting evidence, given that the case study company was still in the early stages of its initial start-up. 


\section{CONCLUSION AND FURTHER RESEARCH}

The dominant theme in the internationalization of SMEs, particularly, "Born Globals" literature has paid little attention to the influence of social networks. However, even within the limited studies, almost all of the research focuses on the merits of social networks. This research was motivated by the insufficient knowledge about the negative effects of social networks on the de-internationalization of "Born Global" firms. The present research focused on a rare case of a small high-tech firm in the UK whose business is purely internationally orientated. We investigated how social networks influence its initiation of the internationalization process. The analysis of the case firm uncovered some potentially negative effects of social networks. Some elements of social networks formation, such as online social networks and relationships management system deserve more research attention. There is a need for further research to investigate "unsuccessful factors" or "pitfalls" of social relationship in order to generate a guideline for entrepreneurs to minimize their errors. The social networks impact on "de-internationalization" should receive researchers' attention. From the research findings above, there also a need to explore the influence of online or internet social networks on the "Born Global" internationalization process in depth.

The findings of the present research suggest that every entrepreneur base their internationalisation strategy on prior experience and perception. Actions are based on perceptions, therefore, the internationalisation process occurs to a large extent in the international entrepreneurs' minds. Furthermore, social networks play a big "plug" role in the initiation of internationalisation which could be, in fact, preventing the international start-up process, particularly in rapidly growing "Born Global" firms. Further theoretical contributions of the present study include the exploration of a potentially negative influence of social networks on the internationalisation that has been ignored from a rational perspective; the identification of online social networks towards the internationalisation and the significance of high-tech communication and management techniques support in the growth of "Born Globals". From the case study, the de-internationalisation phenomenon can be described as a negative result which can be triggered by social networks impairment.

\section{REFERENCES}

Aldrich, H., Reese, P. R., \& Dubini, P. (1989). Women on the verge of a breakthrough: Networking among entrepreneurs in the United States and Italy. Entrepreneurship \& Regional Development, 1(4), 339-356. doi:10.1080/08985628900000029

Aldrich, H. E. (2001). Who wants to be an evolutionary theorist. Journal of Management Inquiry, 10(2), 115-127. doi:10.1177/1056492601102004

Anderson, A. R., \& Jack, S.L. (2002). The articulation of social capital in entrepreneurial networks: A glue or a lubricant? Entrepreneurship \& RegionalDevelopment, 14(3), 193-210. doi:10.1080/08985620110112079

Autio, E., \& Sapienza, H. J. (2000). Comparing process and born global perspectives in the international growth of technology-based new firms. Helsinki University of Technology.

Axelsson, B., \& Agndal, H. (2000). Internationalization of the Firm. A Note on the Crucial Role of the Individual's Contact Network. Or Fragments to a Theory of Individual Relationship Sediments and Opportunity Networks as Driving Forces and Enablers of Internationalization. thIMP conference, Bath, UK. 
Bell, J. (1995). The internationalization of small computer software firms: A further challenge to "stage" theories. European Journal of Marketing, 29(8), 60-75. doi:10.1108/03090569510097556

Bell, J., Crick, D., \& Young, S. (2004). Small Firm Internationalization and Business Strategy: An Exploratory Study of Knowledge-Intensive and Traditional Manufacturing Firms in the UK. International Small Business Journal, 22(1), 23-56. doi:10.1177/0266242604039479

Benito, G. R. G., \& Welch, L. S. (1997). De-internationalization. Management International Review, $37,7-25$.

Calof, J. L., \& Beamish, P. W. (1995). Adapting to Foreign Markets: Explaining Internationalization. International Business Review, 4(2), 115-131. doi:10.1016/0969-5931(95)00001-G

Chetty, S. (1999). Dimensions of internationalization of manufacturing firms in the apparel industry. European Journal of Marketing, 33(1/2), 121-142. doi:10.1108/03090569910249201

Chetty, S., \& Campbell-Hunt, C. (2004). A Strategic Approach to Internationalization: A Traditional Versus a Born-Global Approach. Journal of International Marketing, 12(1), 57-81. doi:10.1509/ jimk.12.1.57.25651

Child, J., \& Hsieh, L. H. (2014). Decision mode, information and network attachment in the internationalization of SMEs: A configurational and contingency analysis. Journal of World Business, 49(4), 598-610. doi:10.1016/j.jwb.2013.12.012

Coviello, N. (2015). Re-thinking research on born globals. Journal of International Business Studies, 46(1), 17-26. doi:10.1057/jibs.2014.59

Coviello, N. E. (2005). Integrating qualitative and quantitative techniques in network analysis. Qualitative Market Research: An International Journal, 8(1), 39-60. doi:10.1108/13522750510575435

Crick, D., \& Jones, M. V. (2000). Small high-technology firms and international high-technology markets. Journal of International Marketing, 8(2), 63-85. doi:10.1509/jimk.8.2.63.19623

Cummings, J. N., Butler, B., \& Kraut, R. (2002). The quality of online social relationships. Communications of the ACM, 45(7), 103-108. doi:10.1145/514236.514242

Easton, G. (1995). Case research as a methodology for industrial networks: a realist apologia. Industrial Marketing and Purchasing (IMP) International Seminar.

Ellis, P. (2000). Social Ties and Foreign Market Entry. Journal of International Business Studies, 31(3), 443-469. doi:10.1057/palgrave.jibs.8490916

Ellis, P., \& Pecotich, A. (2001). Social factors influencing export initiation in small and medium-sized enterprises. JMR, Journal of Marketing Research, 38(1), 119-131. doi:10.1509/jmkr.38.1.119.18825

Holmlund, M., \& Kock, S. (1998). Relationships and the Internationalisation of Finnish Small and MediumSized Companies. International Small Business Journal, 16(4), 46-63. doi:10.1177/0266242698164003

Johanson, J., \& Vahlne, J.-E. (2003). Business Relationship Learning and Commitment in the Internationalization Process. Journal of International Entrepreneurship, 1(1), 83-101.doi:10.1023/A:1023219207042 
Jones, M. V. (1999). The internationalization of small high-technology firms. Journal of International Marketing, 7, 15-41.

Klyver, K., \& Schott, T. (2003). Entrepreneurs' personal networks: Encouragement or criticism? Paper presented at LoK Conference (Middelfart).

Knight, G. (2000). Entrepreneurship and Marketing Strategy: The SME Under Globalization. Journal of International Marketing, 8(2), 12-32. doi:10.1509/jimk.8.2.12.19620

Knight, G. A., \& Cavusgil, S. T. (1996). The Born Global Firm: A Challenge to Traditional Internationalization Theory. Advances in International Marketing, 8, 26.

Komulainen, H., Mainela, T., \& Tahtinen, J. (2006). Social networks in the initiation of a high-tech firms internationalisation. International Journal of Entrepreneurship and Innovation Management, 6(6), 526-541. doi:10.1504/IJEIM.2006.010979

Komulainen, H., Mainela, T., \& Tähtinen, J. (2004). Social networks in the initiation of the high tech firm's internationalization. Proceeding of the 20th IMP Conference.

Liesch, P. W., Nummela, N., \& Welch, C. (2014). About time: Putting process back into firm internationalisation research. Management International Review.

Madsen, T. K. \& Servais, P. (1997). The internationalization of Born Globals: an evolutionary process? International Business Review, 6(6), 561-83.

Mainela, T. (2002). Networks and Social Relationships in Organizing International Joint Ventures: Analysis of the Network Dynamics of a Nordic-Polish Joint Venture (PhD Thesis). Universitas Wasaensis.

Mcdougall, P. P., Shane, S. A., \& Oviatt, B. M. (1994). Explaining the formation of international new ventures: The limits of theories from international business research. Journal of Business Venturing, 9(6), 469-487. doi:10.1016/0883-9026(94)90017-5

Mejri, K., \& Umemoto, K. (2010). Small-and medium-sized enterprise internationalization: Towards the knowledge-based model. Journal of International Entrepreneurship, 8(2), 156-167. doi:10.1007/ s10843-010-0058-6

O Donnell, A., \& Cummins, D. (1999). The use of qualitative methods to research networking in SMEs. Qualitative Market Research: An International Journal, 2(2), 82-91. doi:10.1108/13522759910269991

ODonnell, A. (2014). The contribution of networking to small firm marketing. Journal of Small Business Management, 52(1), 164-187. doi:10.1111/jsbm.12038

Oviatt, B. M. B., \& Mcdougall, P. P. P. (1994). Toward a Theory of International New ventures. Journal of International Business Studies, 25(1), 45-64. doi:10.1057/palgrave.jibs.8490193

Rennie, M. W. (1993). Global competitiveness: Born global. The McKinsey Quarterly, 4, 45-52.

Rialp, A., Rialp, J., \& Knight, G. A. (2005). The phenomenon of early internationalizing firms: What do we know after a decade (1993-2003) of scientific inquiry? International Business Review, 14(2), 147-166. doi:10.1016/j.ibusrev.2004.04.006 
Saunders, M. N. (2011). Research methods for business students. Pearson Education India.

Stenbacka, C. (2001). Qualitative research requires quality concepts of its own. Management Decision, 39(7), 551-555. doi:10.1108/EUM0000000005801

Styles, C., Gray, S., Sullivan Mort, G., \& Weerawardena, J. (2006). Networking capability and international entrepreneurship: How networks function in Australian born global firms. International Marketing Review, 23(5), 549-572. doi:10.1108/02651330610703445

Vissak, T., \& Francioni, B. (2013). Serial nonlinear internationalization in practice: A case study. International Business Review, 22(6), 951-962. doi:10.1016/j.ibusrev.2013.01.010

Yin, R. K. (2003). Case Study Research: Design and Methods 3rd. Sage (Atlanta, Ga.).

Zikmund, W. (1994). Business research methods. The Dryden Press.

\section{KEY TERMS AND DEFINITIONS}

Born Global: Firms are engaging in international operations in the early days of their establishment. Case Study: A research strategy investigating a phenomenon within its real-life context.

De-Internationalisation: Any voluntary or forced actions that reduce a firm's international activities. Entrepreneurs: Those business owners launch and run a new company.

Impairment: The state or fact of being impaired or damaged.

Negative Impact: Those drawbacks and obstacles decreasing a company's performance.

Social Networks: One's relations and contacts with others at the personal-level.

\section{ENDNOTES}

$1 \quad$ Skype ${ }^{\mathrm{TM}}$ is a programme allowing telephone conversations via the Internet. Calls to other Skype ${ }^{\mathrm{TM}}$ users are free as well as calls to regular telephone and mobile telephone numbers all over the world are at a low rate.

2 The .NET Messenger Service is an instant messaging system developed by Microsoft. It works together with Microsoft's Passport system to allow users to send messages to each other online.

3 A chat program that can be set to notify the user when friends are online; it seeks out friends of the user so messages and files can be exchanged. 